Check for updates

The BMJ

Cite this as: $B M J 2021 ; 375: n 3159$ http://dx.doi.org/10.1136/bmj.n3159 Published: 30 December 2021

\section{Omicron: NHS is on "war footing" as Nightingale hubs are announced in England}

\author{
Elisabeth Mahase
}

Temporary hubs will be set up in the grounds of eight hospitals around England as a precaution against a potential surge in admissions due to the current record number of covid-19 infections, the government has announced.

The "Nightingale hubs" will be able to take around 100 patients each, and construction will start in the first week of 2022 as part of preparations for a potential wave of admissions with the omicron variant. On 29 December the UK reported 183037 new cases of covid-19, with a seven day average of 118000 new cases a day to 21 December.

The hubs would be expected to take patients who are not fit for discharge but need minimal support and monitoring while recovering from illness, such as people recovering from covid-19 who are no longer infectious and do not need intensive oxygen therapy.

During the first wave of the pandemic in 2020 the government set up five emergency Nightingale hospitals, but they closed without seeing many patients, leading to questions about whether resources were disproportionately focused on building intensive care capacity. ${ }^{2}$

Staffing was also a major issue. David Oliver, geriatrics and acute general medicine consultant, wrote in The BMJ in August that "hospitals need staff, not just beds and equipment. The NHS has one in eight nursing posts and one in 11 other clinical positions unfilled. Where would the staff come from?"3

\section{Hospital sites}

Unlike last time, the government has said that it will locate the hubs inside hospital grounds to make it easier to "flex staff and equipment if there is a surge in admissions, providing access to diagnostics and emergency care if required."

However, this has not eased concerns. Vishal Sharma, chair of the BMA's Consultants Committee, said, "There are already over 100 ooo staff vacancies in the NHS, and we don't simply have a bank of spare doctors waiting to take up jobs. To compound the problem, thousands of healthcare workers are currently infected with covid-19 and having to isolate.

"The government needs to be absolutely clear about how these Nightingale sites will operate, where the staff might come from, and what the impact could be on other healthcare services if doctors and other healthcare professionals are to be diverted from providing non-covid care and services.”

The first eight hubs will be built at the Royal Preston Hospital, St James's University Hospital Leeds, Solihull Hospital, University Hospitals Leicester,
Lister Hospital Stevenage, St George's Hospital London, William Harvey Hospital Ashford, and North Bristol Hospital.

Stephen Powis, NHS national medical director for England, said, "Given the high level of covid-19 infections and increasing hospital admissions, the NHS is now on a war footing. We hoped never to have to use the original Nightingales, and I hope we never have to use these new hubs. Staff across the health service are working around the clock to provide the best possible care to patients and roll out the NHS covid vaccination programme."

NHS trusts have also been tasked with identifying other venues, such as gyms and education centres, that could be converted into additional Nightingale sites to increase the total number of extra beds to 4000.

1 Gov.uk. Cases in United Kingdom. Dec 2021. https://coronavirus.data.gov.uk/details/cases?areaType=0verview\&areaName=United\%20 King dom

2 Day M. Covid-19: Nightingale hospitals set to shut down after seeing few patients. BM/2020;369:m1860. doi: 10.1136/bmi.m1860 pmid: 32381503

3 Oliver D. David Oliver: Were Nightingale units and fever hospitals ever workable responses to covid-19?BM/2021;374:n2013. doi: 10.1136/bmj.n2013 pmid: 34407959

This article is made freely available for use in accordance with BMJ's website terms and conditions for the duration of the covid-19 pandemic or until otherwise determined by BMJ. You may use, download and print the article for any lawful, non-commercial purpose (including text and data mining) provided that all copyright notices and trade marks are retained. 